\title{
The space of politics and the space of war in Hugo Grotius's De iure belli ac pacis
}

\author{
Annabel Brett
}

\section{INTRODUCTION}

It has become increasingly common, in both history and political theory, to pay attention to space. The idea of a 'spatial turn' in history, reading for the spaces of human interaction as an essential part of thinking about that interaction itself, is very familiar by now. In political theory, likewise, there has been a wealth of new literature on political spaces and their frontiers, including a renewed attention to territory as a political phenomenon and concept. But the concept of space has yet to permeate, in any systematic way, the study of the history of political thought, even though the picture is beginning to change for intellectual history more broadly. ${ }^{1}$ Considerations of European political thought from a spatial perspective tend to come from scholars who are, at least to some extent, outside the discipline of the history of political thought. ${ }^{2}$ The reasons for this lie partly in disciplinary boundaries and different historiographical traditions. But it is also because many of the political theories offered by key figures of the Western tradition do not themselves systematically highlight space as a key element of human politics. Hobbes's Leviathan represents, at least on the surface, a clear case of this. The state is an artificial man constructed by natural men through a covenant, that is, a mutual act of will. It is thus an inter-personal rather than a spatial phenomenon. ${ }^{3}$ And the state so constructed is itself, in turn, capable of acting at will: it is a person, though not a natural one. In short, the juridical metaphysics that makes the state, and makes the state an agent, seems to pull directly against an intrinsically spatial conception of it. ${ }^{4}$ Moreover, this is so for politics not merely in its domestic but also in its international dimension, a dimension that is receiving increasing attention, this time from within the

Versions of this paper have been presented at the University of Chicago, Ohio State University and Princeton University. I would like to thank members of the audience for their comments, both oral and written, on those occasions, as well as the two anonymous readers for Global Intellectual History.

${ }^{1}$ David Armitage, 'The international turn in intellectual history', in D. M. McMahon and S. Moyn eds., Rethinking modern European intellectual history (New York: Oxford University Press, 2014), 232-252, and John Randolph, 'The space of intellect and the intellect of space', in the same volume, 212-231, draw attention to both the possibilities and the difficulties of deploying the concept of space in intellectual history.

${ }^{2}$ Thus, considerations of European political thought from a spatial perspective tend to come from scholars who are, at least to some extent, outside the discipline of the history of political thought, for example Carlo Galli, Spazi politici (2001), tr. E Fay in A. Sitze ed., Political spaces and global war (Minneapolis: University of Minnesota Press, 2010); Jens Bartelson, Visions of world community (Cambridge: Cambridge University Press, 2009); Stuart Elden, The birth of territory (Chicago and London: University of Chicago Press, 2013); Lauren Benton, A search for sovereignty. Law and geography in European empires, 1500-1900 (Cambridge MA: Harvard University Press, 2010).

${ }^{3}$ See L. Foisneau, 'Security as a norm in Hobbes's theory of war: A critique of Schmitt's interpretation of Hobbes's approach to international relations', in O. Asbach and P. Schröder eds., War, the state and international law in seventeenth-century Europe (Aldershot: Ashgate, 2010), 163-180.

${ }^{4}$ I have elaborated on this point in Changes of state. Nature and the limits of the city in early modern natural law (Princeton and Oxford: Princeton University Press, 2011), Introduction and Chh. 7-8. 
history of political thought. ${ }^{5}$ The early modern and subsequently modern construction of the international order in terms of sovereign states exported the same juridical metaphysics to the international arena, prioritising personality over spatiality. The post-Hobbesian conception of the equality of states as moral persons became an anchor of the 'law of nations' not only as a legal but a broader political discourse, an optic through which it was impossible to see the existence of empire in its very physical vastness and enormity. ${ }^{6}$ To read for space in many of the canonical texts of the history of political thought, then, is to read deliberately against the grain, with all the risks - although also the potential rewards - that that entails.

It is not, of course, the case that all historical thinking about the international political order has been formulated within a legal idiom in which spatial relations are discounted. In the sixteenth and seventeenth centuries, the discourse of 'reason of state' evolved, within its capacious parameters, a sophisticated discussion of 'the greatness of states' in terms of material resources including population and territorial expanse. The eighteenth century, in turn, saw the development of a fullyfledged economic analysis of international politics in terms of commercial rivalry, as well as setting itself to think seriously about size in relation to states, especially (but not only) in the context of empire. Nor was the discourse of natural law and the law of nations insulated from these other languages in which spatiality was more to the fore. The interaction between them has been emphasised and examined by Richard Tuck, István Hont and others. ${ }^{7}$ In this paper, however, my aim is to explore the intersection between politics, space and agency within the juridical framework of one canonical text of the latter tradition, Hugo Grotius's De iure belli ac pacis (henceforth DIBP), first published in $1625 .^{8}$

Tuck's Natural rights theories of 1979 revived Grotius as a critical figure in the development of early modern natural rights discourse. ${ }^{9}$ Much subsequent scholarship, including my own, has been indebted to this perspective, viewing Grotius's legal and political thought through the lens of natural law and natural rights. In the course of this paper, however, I suggest that too exclusive a focus on the

\footnotetext{
${ }^{5}$ See David Armitage, Foundations of modern international thought (Cambridge: Cambridge University Press, 2013).

${ }^{6}$ I owe this thought to Jennifer Pitts in her unpublished paper 'Law of nations, world of empires: The politics of law's conceptual frames', presented to the conference 'History, politics, law: Thinking through the international', held May $16^{\text {th }}-17^{\text {th }} 2016$, Cambridge UK. My thanks to the author for permission to cite. ${ }^{7}$ Richard Tuck, Philosophy and government, 1572-1651 (Cambridge: Cambridge University Press, 1993); id., The rights of war and peace. Political thought and the international order from Grotius to Kant (Oxford: Oxford University Press, 1999); István Hont, Jealousy of trade. International competition and the nation-state in historical perspective (Cambridge, MA-London: Harvard University Press, 2005).

${ }^{8}$ Partly for ease of reference, but partly also for the historical interest of the commentary, I have worked principally from Jean Barbeyrac's edition of Amsterdam 1720, the eighteenth-century English translation of which is readily available as Hugo Grotius, The rights of war and peace, ed. R. Tuck (Indianapolis: Liberty Fund, 2005). However, I have used Barbeyrac's edition in conjunction with the original edition of Paris 1625 , and the translations offered here are my own. I have also consulted the edition of B.J.A. de Kanter-van Hettinga Tromp, with new annotations by R. Feenstra and C.E. Persenaire (Aalen: Scientia Verlag, 1993).

${ }^{9}$ Richard Tuck, Natural rights theories. Their origin and development (Cambridge: Cambridge University Press, 1979).
} 
naturalist paradigm of the individual agent armed with natural rights obscures the spatial dimension of Grotius's thought, which is bound up with his analysis of the ineluctably spatial activity of war. Grotius's handling of the legality of war appeals, in addition to natural law, to the 'voluntary law of nations', and this involves an understanding of the situatedness of political community which cannot be reduced to the model of individual agency. In parallel, much of the best recent scholarship has insisted on the importance of Grotius's first work of natural law, De iure praedae (unpublished except for Chapter 12 which was reworked as Mare liberum in 1609), and of understanding DIBP in relation to the earlier work. ${ }^{10}$ In the present article, however, I read DIBP to some extent in isolation from De iure praedae, in order to highlight some of its distinctive new references and strategies. While in both works Grotius is preoccupied with empire as an underlying motive and concern, I suggest that in this later work he is as much interested in land as in sea and that it is on the question of the relationship between land and political community that he offers some of his most subtle and suggestive new thinking. Finally, I do not want to lose the dimension of agency entirely: space is the space not only of politics but of action, and thinking about agency in both war and politics is critical for thinking about spatiality, as well as vice versa. The first two sections of the paper, accordingly, attempt to map the terrain of politics and war; the third considers how that terrain interacts with actors and their agency in both. It is through the involvement of agency that the spatial analysis returns to the agency and indeed the personality of the state.

\section{I - THE SPACE OF POLITICS}

I begin with the space of politics. As we shall see later on, there is a question mark over whether that word is apt for Grotius at all: on one reading, his juridical enterprise is precisely to get out from under the shadow of the Aristotelian polis. ${ }^{11}$ But bracketing that issue for the moment, by 'politics' here I mean, so far as Grotius is concerned, the two kinds of voluntary arrangement that human beings enter into which have the net result of creating a public rather than a private right over them. These are 'consociation' and 'subjection', which are supervenient on the natural society that is enjoined and protected by natural law. Grotius in the Prolegomena to DIBP mentions these two forms as if they were equally original forms of political arrangement into which individual human beings have entered. ${ }^{12}$ But it becomes clear in the course of the work that the political subjection envisaged is on

\footnotetext{
${ }^{10}$ See, in addition to the works of Richard Tuck cited in the previous notes, Martine van Ittersum, Profit and principle. Hugo Grotius, natural rights theories and the rise of Dutch power in the East Indies (1595-1615) (Leiden: Brill, 2006); Hans W. Blom ed., Property, piracy and punishment. Hugo Grotius on war and booty in De iure praedae (Leiden: Brill, 2009); Peter Borschberg, Hugo Grotius, the Portuguese and free trade in the East Indies (Singapore: NUS Press, 2011); Benjamin Straumann, Roman law in the state of nature. The classical foundations of Hugo Grotius's natural law (Cambridge: Cambridge University Press, 2014).

${ }^{11}$ Straumann, Roman law in the state of nature, p. 119.

${ }^{12}$ DIBP, Prolegomena, n.15: qui se coetui alicui aggregaverant aut homini hominibusque [sic; hominibusve, 1625] subjecerant.
} 
the part of a group of individuals who already form a populus, a 'people', which Grotius treats as equivalent to a civitas (the Latin translation of the Greek 'polis') as long as that populus has not surrendered itself to alien rule. ${ }^{13}$ Thus, the original political structure is a legal association between individuals, forming a united body of the people (universitas), in which public power rests with that body, governed by majority vote. ${ }^{14}$ In Book I, where Grotius handles the nature of the civitas en route to explaining the nature and existence of sovereign power, he is famously insistent that the original configuration does not have to stand for all time as the criterion of political legitimacy: the people can entirely alienate its power, if it so wills. But it nevertheless remains what Grotius calls the 'common subject' of that power, even though its ruler is the 'proper subject'.

Some underlying sense of place is involved in this story through the language of coire for the original movement of forming a political community, which Grotius terms a 'consociation'. ${ }^{15}$ In such a community, for Grotius (as for the Spanish scholastics Luis de Molina and Francisco Suárez), it is heads of household rather than individuals who come together. ${ }^{16}$ Nevertheless, in Grotius's handling, consociatio is strictly a juridical relationship between persons. ${ }^{17}$ It is very important too, as we shall see below, that this relationship can move from place to place intact: a people can remain a people even in exile, and is thus not intrinsically linked to any particular place. It might seem, then, that DIBP is a clear case of the inter-personal paradigm to which I referred in the Introduction. However, Grotius's interest in the movement of peoples itself suggests the spatial dimension to his political thought, and in the following two subsections I try to reconstruct this dimension from two different

\footnotetext{
${ }^{13}$ DIBP II.5.31.

${ }^{14}$ DIBP II.5.17 and 23. On this construction, see Brett, Changes of state, pp. 134-138; Richard Tuck, The sleeping sovereign. The invention of modern democracy (Cambridge: Cambridge University Press, 2015), pp. 71-85.

${ }^{15}$ The term consociatio is most firmly associated with the north German Calvinist Aristotelian Johannes Althusius in his Politica methodice digesta, first published in 1603, but there is no direct evidence that Grotius had read his work (which does not exclude the possibility that he had, as noted by Eric Wilson, Savage republic. De Indis of Hugo Grotius, republicanism, and Dutch hegemony within the early modern world system (LeidenBoston: Martinus Nijhoff, 2008), at p. 193). It is also used, however, by the Spanish lawyer Diego de Covarruvias y Leyva, whom Grotius mentions explicitly, and favourably, in the Prolegomena: Practicarum quaestionum liber unus (1554), cap. I, in Tom. II of his Opera omnia (Frankfurt 1592).

${ }^{16}$ DIBP II.5.23: Consociatio, qua multi patres familiarum in unum populum ac civitatem coeunt. Compare Luis de Molina, De iustitia et iure (Mainz 1614), Tract. II, dist. 22; Francisco Suárez, De legibus ac Deo legislatore (Madrid: CSIC 1970-82), Lib. III, cap. 2, n. 3. Both Molina and Suárez are cited in DIBP, and one of the purposes of this paper is to suggest how Grotius's reading of scholastic thought shaped his arguments in this work. Citation is not necessarily an index of actual reading, of course: as Martine van Ittersum shows in a recent consideration of Grotius's early work, his citations of medieval theologians and canonists, including Aquinas, appear to be largely derivative from sixteenth-century authors such as Vitoria and Cajetan. But that same argument demonstrates that Grotius did read some of the major late scholastics quite carefully, and I think that the pattern of reference in DIBP is unintelligible except on the supposition not merely of a familiarity, but also of a positive engagement, with their works (an engagement which also extends to unacknowledged borrowing: I discuss a likely instance of this below, n. 79). Grotius acknowledges their soundness 'in moral matters', in re morum, in the Prolegomena (n. 52), and it is their conception of specifically moral reasoning to which I think he is indebted. See M. van Ittersum, 'The working methods of Hugo Grotius in his early writings', in P.J. du Plessis and J.W Cairns eds., Reassessing legal humanism and its claims. Petere fontes? (Edinburgh: Edinburgh University Press, 2016), 154-193. I am grateful to the anonymous reader for drawing my attention to this article. ${ }^{17}$ Besides the mention in the Prolegomena, the notion is most fully explained in Book II Chapter 5, 'Concerning the original acquisition of right over persons'.
} 
angles. It should be acknowledged at the outset that, here as elsewhere, 'space' in itself is elusive: unless it is deliberately used in an abstract, 'geometric' sense - which is not in question here -, space tends to slide into aspects of bodies such as place or situation, size, relative distance, local motion or travel, as well as into metaphor so pervasive as to inflect what is apparently non-metaphorical usage. ${ }^{18}$ That is, unless it is the direct object of theoretical discourse, space always seems to be something else. Much like power, it is articulated through other things, and exists only in that articulation: a mediated existence that is at once hard to confront and nevertheless partially constitutive of the very things through which it is mediated. In what follows I embrace this diffuse conception of space as part of the very political way of thinking that is the ultimate object of the analysis.

\section{I-Tracking the occupation of space}

In a major recent study, Andrew Fitzmaurice has argued that, in the early modern sources, 'the relation between political society and the place in which people lived was made tangible through occupation' (occupation being the originally Roman legal principle whereby, under natural law, what belongs to no one becomes the property of the first person physically to grasp hold of it). ${ }^{19} \mathrm{He}$ is certainly right to point to the central role of occupation, but there are complications involved in the case of DIBP because in two key respects Grotius did not appeal purely to that concept. First, as Fitzmaurice recognises, Grotius in Chapter 2 of Book II of DIBP ('Concerning the original acquisition of right in things') deployed in addition a scholastic - or at least, broadly theological - concept of 'division' following the original common ownership of things. ${ }^{20}$ In the hands of sixteenth-century scholastics such as Francisco de Vitoria and Domingo de Soto, division is at the heart of the ius gentium, the law of nations. It is explained through a spatio-temporal story, largely taken from sacred history, of the descendants of Noah spreading out and settling the islands of the globe, and again of Abraham and Lot going their separate ways. ${ }^{21}$ In Grotius's hands, the Flood is only one moment in the story of division, which Grotius rolls together with the tower of Babel. Nevertheless, as his chapter 'Concerning the original acquisition of right in things' makes clear, it is still division which is the

\footnotetext{
${ }^{18}$ See Armitage, 'The international turn', p. 240; Randall, 'The space of intellect', p. 217.

${ }^{19}$ Andrew Fitzmaurice, Sovereignty, property and empire, 1500-2000 (Cambridge: Cambridge University Press, 2014), p. 22. Fitzmaurice argues that it is a mistake to read the concept of res nullius back onto the Roman law of occupation, or onto other texts which do not specifically use that locution, even if they appeal to the more general notion of something belonging to no one (nullius): ibid., pp. 51-58. For a contrasting perspective see Lauren Benton and Benjamin Straumann, 'Acquiring empire by law', Law and History Review 28.1 (2010), 138 , who also stress the variety of purposes to which occupatio could be turned in early modern imperial legal argument. Grotius certainly used the term res nullius itself.

${ }^{20}$ Fitzmaurice, Sovereignty, property and empire, pp. 97-8.

${ }^{21}$ See Brett, Changes of state, pp. 196-199. The language of 'division' appears in the Latin Vulgate, Genesis $10.5,10.32:$ ab his divisae sunt insulae gentium in regionibus suis unusquisque secundum linguam et familias in nationibus suis (AV: 'By these were the isles of the Gentiles divided in their lands; every one after his tongue, after their families, in their nations'); ab his divisae sunt gentes in terra post diluvium (AV: 'by these were the nations divided in the earth after the Flood)'. In the Protestant Latin translation of Immanuel Tremellius and Franciscus Junius, the language of 'division' similarly occurs in both places.
} 
original mode of generating right in lands, with occupation a subsequent moment. ${ }^{22}$ This story, with its biblical references, is absent from the accounts of the genesis of property in De iure praedae and Mare liberum, for which the sources are almost entirely Roman. ${ }^{23}$

Thus, Grotius narrates, in the beginning all things were common to all, by gift of God, a gift that was repeated after the Flood when the world was restored. That does not mean that individuals had no juridical purchase of their own on any of those things. What there was for individuals was a 'use of the universal right' (usus universalis iuris), which Grotius illustrated with the famous example from Cicero of someone 'occupying' a theatre seat. But this was not the 'occupation' that made a thing one's own. The occupation of something communis rather than nullius had the legal form of usus iuris (rightful use) rather than property or dominium. ${ }^{24}$ However, the invention of the arts, the end of primitive simplicity, put an end to this legal world. The first brothers, Abel and Cain, practised their different skills 'not without a certain distribution of things' (non sine aliqua rerum distributione). But this led to emulation, and even to slaughter (caedes) and the 'life of giants, that is, of violence' (vitae genus giganteum, i.e. violentum). This savage world was purged by the Flood, but more trouble ensued, this time from wine and pleasure. ${ }^{25}$ However, it was 'a more noble vice, ambition, the sign of which was the tower of Babel' that decisively ruptured the state of harmony (concordia), and thereafter 'different [individuals] possessed different lands separately' (alii alias terras partito possederunt). ${ }^{26}$ Even at this point, there was still common pastureland between neighbours. But eventually, when the number of men and flocks increased, the lands began to be divided, not into gentes ('nations') as heretofore, but into families, familiae. ${ }^{27}$ In the first mention of occupation as creating a property right for the occupier, Grotius tells us that wells, 'very necessary in a dry region', were occupied (rather than divided), and thereby belonged to the person who occupied them. ${ }^{28}$

What Grotius offers, in this compressed and not entirely clear account, is a kind of juridical commentary the narrative that Genesis presents, of people simultaneously in relation to other people and in relation to land and features of the land like wells. ${ }^{29}$ The contours of the original division of the

\footnotetext{
${ }^{22}$ DIBP II. 2. Edmund Keene, Beyond the anarchical society. Grotius, colonialism and order in world politics (Cambridge: Cambridge University Press, 2002), also notes the primordial moment of 'division' (p. 53 n. 38).

${ }^{23}$ Hugo Grotius, De iure praedae commentarius, tr. G. L. Williams in M. van Ittersum ed., Commentary on the law of prize and booty (Indianapolis: Liberty Fund, 2006), Ch. 12, pp. 315-323; Mare liberum, ed. D. Armitage (Indianapolis: Liberty Fund, 2004), Ch. 5, pp. 20-26.

${ }^{24}$ DIBP II.2.2.1.

${ }^{25}$ DIBP II.2.2.2.

${ }^{26}$ DIBP II.2.2.3. The marginal reference is to Genesis 10 and 11.

${ }^{27}$ The marginal reference at this point in the 1625 edition is to Genesis 13, the story of Abraham and Lot, which constituted a paradigm of division for scholastic authors such as Vitoria. In Barbeyrac's edition this note has been slightly displaced.

${ }^{28}$ DIBP II.2.2.3; the reference is to Genesis 21, the story of Hagar sent out into the wilderness, and subsequently the dispute between Abraham and Abimelech over a well.

${ }^{29}$ There is much more to be said on the operation of both exegesis and exemplarity in Grotius's handling of the biblical narrative, a theme that I hope to develop elsewhere. My thanks to Michèle Lowrie and to Alex Kaye for pointing out to me the importance of these dimensions.
} 
lands into gentes remain uncertain, however, as Grotius gives no further hint here as to who the gentes are - whether, for example, they include the Libyan Garamantes who come up later on as an example of a gens; or the Scythians, or the Germans; or the gentes of America, the object of Grotius's later (1642) Dissertatio de origine gentium americanarum. ${ }^{30}$ However, in the subsequent section of Chapter 2, which explains why the high seas are still in common, Grotius deployed not merely the argument from occupation which had characterised his earlier (1604-5) De iure praedae (something indefinite, and fluid, such as the sea, cannot be occupied), but also an argument from division. Granted the sea cannot be occupied, he insisted, 'neither can we invent a division: for when the lands were first divided, the greatest part of the sea was unknown; and because of that no way can be imagined by which nations placed so far apart (gentes adeo dissitae) could agree on a division. ${ }^{31}$ The reasoning seems to be that nations who had not discovered the oceans to their full extent could not sail across them to agree to divide them up (division, Grotius stresses, requires express consent, whereas occupation involves tacit consent). ${ }^{32}$ It seems clear, then, that division is a global story about the entire earth that created an original geo-political order, even if its contours are uncertain. ${ }^{33}$ Grotius is insistent that after those 'first times', division was no longer a possible mode of acquisition of right in the land; only occupation remains as a source of new right. ${ }^{34}$ Certainly, this puts a premium on 'occupation' in the acquisition of right; but it is also important to note that occupation operates only within an existing spatial order of gentes, even if there remain (rather - and purposefully? - vaguely) 'many places still uncultivated (loca adhuc inculta)', and 'islands in the sea'. Grotius's note here points the reader to Book VI of Pietro Bembo's Historiae Venetae, which recounts Columbus's voyage and subsequent Spanish and Portuguese explorations in America and in Africa. ${ }^{35}$

Grotius ends his section on the original division with a passage of almost Schmittian flavour: 'when the ancients called Ceres a lawgiver, and called her rites the Thesmophoria [thesmos meaning a law in the sense of something that has been laid down], they signified this, that from the division of the fields

\footnotetext{
${ }^{30}$ See Joan-Pau Rubiés, 'Hugo Grotius's Dissertation on the Origin of the American Peoples and the Use of Comparative Methods', Journal of the History of Ideas 52, 2 (1991), 221-44.

${ }^{31}$ DIBP II.2.3.2

${ }^{32}$ DIBP II.2.2.5. Fitzmaurice, Sovereignty, property and empire, pp. 94-97, stresses the role of consent in the creation of property by occupation in DIBP, differently from De iure praedae. In his reading this puts occupation second, although as he also remarks (p. 98), simple occupation continues to play a key role in Grotius's juridical story. Straumann, Roman law in the state of nature, p. 186, suggests rather the simultaneity of occupation and consent, which I think is closer to Grotius's account.

${ }^{33}$ It is worth noticing that Verse 8 of Genesis 11, to which Grotius refers (above, n. 22), explicitly refers to the whole world: 'So the Lord scattered them abroad from thence upon the face of all the earth' (AV); ita divisit eos Dominus ex illo loco in universas terras (Vulgate); Sic dispersit illos Iehova inde in superficiem totius terrae (Tremellius-Iunius).

${ }^{34}$ DIBP II.2.3.3: 'those things, which were common to all, and were not divided in the first division, those things come under proper(ty) right not now by division, but by occupation', and II.3.4.1: post prima illa tempora, 'after those first times'.

${ }^{35}$ DIBP II.2.4; Pietro Bembo, History of Venice, tr. Robert W. Ulery Jr. (Cambridge MA-London: Harvard University Press, 2008), Vol. II, pp. 87-107.
} 
there came about the origin of a new ius ${ }^{36}$ That last point is an important one: although the chapter is entitled 'Original acquisition of right in things', which might suggest that the right pre-exists the acquisition, this is not the case. Rather, in the case of original (as opposed to 'derivative') acquisition, the acquisition of the right and the genesis of the right are simultaneous. I think this is the sense of the locution that we shall encounter presently, when Grotius talks of 'occupying' both imperium (which I shall translate 'sovereignty') and dominium. Neither of these were lying around for the taking beforehand, so to speak, but were created in the same moment as the occupation. A patchwork of right is created with the patchwork of the ground.

Grotius goes on to give more detail on how occupation proceeds following those first times, yielding a clearer picture of the patchwork. Here he introduces into his story a second conceptual complication, necessary to account for the occupation of land. Such occupation, he says, can happen in two ways. ${ }^{37}$ The first is per universitatem, universally (the universitas being the corporate body that is created through consociation); the second is per fundos, by farms or estates. Universal occupation happens through the people (populus) or whoever commands (imperat) the people. The second type of occupation occurs by individuals and is said to be in fact more a case of 'assignation' than 'free occupation'. If anything occupied universally has not been marked out for individual ownership (in singulos dominos descriptum), that does not mean it is 'vacant' (vacuum): it belongs to the original occupier, the people or the king. Grotius specifies that these tend to be such things as rivers, lakes, marshes, woods, and steep mountains. The occupation of land, then, is primarily a public act, and the resultant dominium is a kind of public ownership. The underlying model is, in fact, the Roman ager publicus, something that Grotius goes on to confirm by explicit appeal to the Roman agrimensores or land surveyors. Ager publicus was land acquired by the Roman res publica through conquest, and publicly owned. ${ }^{38}$ Grotius's appeal to this legal form in the context of occupation ambiguously fuses public and private, iure gentium and iure naturali modes of acquisition. ${ }^{39}$ With its distinction between public and private occupation - the latter not, in fact, strictly speaking occupation - it refines the analysis offered in De iure praedae and Mare liberum, from Seneca and Cicero, according to which 'the occupancy of public possessions is achieved by the same method as occupancy of private possessions. ${ }^{40}$

\footnotetext{
${ }^{36}$ DIBP II.2.2.5.

${ }^{37}$ DIBP II.2.4.

${ }^{38}$ For ager publicus see Saskia T. Roselaar, Public land in the Roman Republic (Oxford: Oxford University Press, 2010); ibid. pp. 12-14 for the agrimensores. See also Elden, The birth of territory, pp. 82-93.

${ }^{39} \mathrm{Cf}$. Benton and Straumann, 'Acquiring empire by law', p. 29, on 'the purposeful confusion of private and public law'.

${ }^{40}$ Grotius, De iure praedae, ed. van Ittersum, Ch. 12, p. 320; Mare liberum, ed., Ch. 5, p. 24.
} 
Grotius may well have come to know of the corpus agrimensorum from the edition published in 1614 by a member of his new circle of intellectual friends in Paris, Nicolas Rigault. ${ }^{41}$ Rigault was the librarian of Louis XIII, praised for his care in that office by Grotius in his Silva ad Thuanum, a poem addressed to François-Auguste de Thou and published in Paris in 1621 as a form of selfintroduction. ${ }^{42}$ Rigault dedicated his 1614 edition to the king with a letter in which he argued for the utility of the agrimensores in the defining the boundaries of empire (fines imperii), a project that he links firmly with Louis XIII and his reign. Kingdoms in their greatness, he proposed, were like athletes in their prime, needing a little of their strength to be 'deducted' or 'led off': not into allied or friendly states, but by sowing colonies in 'half-savage' and barbarous nations, towns in the deserted wastes. 'New settlements (novae sedes) should be sought for an overflowing France... So, my lord, you will conquer through settling; thus the barbarians will leave behind their savagery and become human beings.... ${ }^{43}$ Grotius in DIBP has nothing like this unashamed justification of overseas settlement in the interests of the mother-country, nor the notorious argument from civilisation, both of which had been deployed not only by Rigault and others in France but also in the Netherlands prior to the formal establishment of the Dutch West India Company in $1621 .{ }^{44}$ If we are looking for the nature and extent of Grotius's imperialism, his distance from this kind of argument is one measure of it. ${ }^{45}$ Nevertheless, DIBP does leave room, not only for further public occupation of any remaining 'uncultivated' places and islands, but also, with caveats, for some kind of private overseas settlement. This position might not only accommodate Dutch visions; it might also be favourable to the commercial ambitions of Louis XIII and Richelieu, who made overtures to Grotius in 1626 even if the latter, fearing the damage it would do to his prospects of a return to the Netherlands, ultimately declined the offer. ${ }^{46}$

\footnotetext{
${ }^{41}$ There existed an earlier edition, De agrorum conditionibus et constitutionibus limitum, by Adrian Turnèbe (Paris 1554), but there is no mention of it in De iure praedae.

${ }^{42}$ See H.J.M. Nellen, 'Grotius et le monde intellectual parisien', in Nederlands Archief voor Kerkgeschiedenis / Dutch Review of Church History 80/3 (2000), 282-295. Grotius would later defend Rigault's interpretation of a passage of Tertullian against attack from Gabriel de l'Aubespine, bishop of Orléans: see H.J.M Nellen, 'Disputando inclarescit veritas: Grotius as a publicist in France, 1621-1645', in H.J.M. Nellen and E. Rabbie eds., Grotius the theologian. Essays in honour of G.H.M. Posthumus Meyjes (Leiden: Brill, 1994), 121-144, at pp. 132-4.

${ }^{43}$ Nicolas Rigault, Auctores finium regundorum (Paris 1614), Ep. Ded. Rigault later published a justification of Louis's policy in the controversy over French intervention in the Valtelline: William F. Church, Richelieu and reason of state (Princeton: Princeton University Press, 1973), p. 138 n. 83.

${ }^{44}$ For the broader intellectual and political context of views such as Rigault's, see Saliha Belmessous, 'Greatness and decadence in French America', Renaissance Studies 26/4 (2012), 559-579, at pp. 565-570; for the Netherlands, Arthur Weststeijn, 'Republican empire: colonialism, commerce and corruption in the Dutch Golden Age', in the same volume of Renaissance Studies, 491-50, at p. 497. Publicists for the Dutch West India Company stressed the need to acquire colonies in the Indies in order to secure Dutch trade: Jonathan Israel, Dutch primacy in world trade, 1585-1740 (Oxford: Clarendon Press, 1989), p. 157.

${ }^{45}$ Fitzmaurice, Sovereignty, property and empire, p. 99; compare Camille Boisen, 'Grotius and empire', Grotiana 36/1 (2015), 28-39.

${ }^{46}$ Erik Thomson, 'France's Grotian moment? Hugo Grotius and Cardinal Richelieu's commercial statecraft', French History 21/4 (2007), 377-394.
} 
In a move that has attracted critical comment from the eighteenth century to the twenty-first, Grotius coupled the Roman model of public land ownership with a variant on the traditional dichotomy between jurisdiction (dominium iurisdictionis) and property (dominium proprietatis). Thus, he argued, there is a distinction between occupation of imperium (sovereignty) and occupation of dominium (property). ${ }^{47}$ Imperium and dominium are most often acquired in single act, but they can be separated, so that dominium can pass to outsiders (extranei) even while imperium remains with the original holder. Grotius appealed for support to a passage from the Roman surveyor Siculus Flaccus's De conditionibus agrorum, on the assignation of agri to coloni.$^{48}$ This separation of imperium from dominium allowed him to argue that not merely individuals, but also entire peoples on the move, can acquire dominium in a foreign land provided they submit to the jurisdiction of that place. ${ }^{49}$ A people is allowed to remain a cohesive public body, even when on the move, by a further split within the notion of imperium conditioned by two different 'subject-matters': imperium over persons and imperium over place, 'which is called territory'. The former 'is sometimes enough, as in a company (exercitus) of men, women and children seeking a new home (novas sedes). ${ }^{50}$ Such communities are by natural law allowed to stay in a host country, and may even rightly 'occupy' any places within that country which are 'sterile and deserted': for, Grotius says, something that is not cultivated should not be thought to be occupied, or at least only in respect of imperium. ${ }^{51}$

As Jean Barbeyrac pointed out in 1720, this passage is in simple contradiction with Grotius's prior insistence that anything occupied by a people or king and not assigned to individual owners remains within the dominium of that people or king. ${ }^{52}$ But Grotius later on appears to retreat from the universality of that prior claim with the remark that sometimes the people or head of the people acquires not only imperium and its accompanying 'eminent domain' (dominium eminens), but also

\footnotetext{
${ }^{47}$ DIBP II.3.4.1. Keene, Beyond the anarchical society, pp. 56-7, underlines the importance of this distinction and its colonial implications. He rightly characterises imperium as public while dominium is private. But it is important that this does not mean that all dominium belongs to private individuals. Grotius's position allows although, as we shall see, it does not in fact require - a public body or agent (the people or its sovereign) to have private dominium over its land.

${ }^{48}$ DIBP II.3.4.2. Flaccus's work could be found in Rigault's edition, and also in Turnèbe's. The specific passage can be found in a modern edition in Siculus Flaccus. Les conditions des terres, tr. M. Clavel-Lévêque et al. (Napoli: Jovene Editore, 1993), p. 100; the facing-page translation reads: 'En outre, lorsque les auteurs de l'assignation et de la division, en cas d'insuffisance des terres d'une colonie, ont pris des terres aux territoires voisins, ils les ont bien assignées à de futurs citoyens de la colonie, mais le pouvoir de juridiction sur ces terres assignées est resté à ceux sur la territoire desquels elles avaient été prises.' The difficulty of the passage is commented on by Grotius's eighteenth-century editor Jean Barbeyrac, who argued (together with the work's 1674 editor, Goesius) that jurisdiction in fact acceded to the colony, hence nullifying Grotius's argument. ${ }^{49}$ DIBP II.2.16.

${ }^{50}$ DIBP II.3.4.1. Notice that the passage suggests there can be no imperium over place without imperium over people, although not vice versa.

${ }_{51}$ DIBP II.2.17.

${ }^{52}$ I.e. DIBP II.2.4; for Barbeyrac's comment see Grotius, The rights of war and peace, ed. Tuck, p. 448, in the note: 'He does not there [sc. at II.2.4] distinguish Jurisdiction from property; and that Distinction is equally ill grounded in this Case, and liable to great Inconveniences.'
} 
'private and full dominium' which it then distributes to individuals. ${ }^{53}$ It is only in such a case that derelict lands do not fall to the occupier. Is there any such case beyond the Roman, though, and what do we presume in case of doubt? Grotius is silent, and it is hard to avoid the depressing conclusion that the analysis is asymmetrically weighted in favour of those states which can offer some kind of proof that they own their land, in the full private sense, and those which, for the most obvious reasons, cannot. It is true that Grotius's talk of peoples or public bodies on the move refers only to exiles, those who have been expelled from their home and are compelled to seek a new place. ${ }^{54}$ In Chapter 22 of Book II, 'On unjust causes', he includes among them the simple 'desire to change location (sedes), so that more fertile ground can be possessed, leaving behind the marshes and the deserts' ${ }^{55}$ The same chapter contains his outright condemnation of the argument from barbarism and natural slavery ('Nor is it less unjust to wish to subdue certain people by force of arms, as if worthy to be slaves'), and his general maxim that 'utility does not create a right equal to that of necessity'. ${ }^{56}$ This restraint might be read as a tacit corrective to Rigault's advocacy of French public settlement in the interests of France. But nevertheless Grotius's argument says nothing against a private trading company, for instance, occupying 'derelict' land for reasons of utility in a place where the people cannot be shown publicly to hold 'private and full' dominium as well as imperium over the place (although the caveat remains that it would have to submit to the imperium of the local inhabitants). In sum, it is not the imperium / dominium distinction per se, but the ambiguity over public ownership, which creates the conditions for colonial exploitation.

Meanwhile, as we have just seen, the imperium / dominium divide has produced a definition - if only the very briefest definition - of territory as place subject to imperium, associating territory clearly with imperium rather than dominium. But the few other passages in the work that explicitly articulate the concept of territory do not sit entirely happily with this definition. Skipping ahead for a moment to Book III, to the question of the acquisition of goods in war, Grotius allows that captured land (ager captus) falls under this heading so long as it is not just temporarily occupied but enclosed in permanent fortifications such that it cannot be recovered by the other side. In this sense he approves Siculus Flaccus's etymology of the word 'territory' from 'terrifying enemies' (a terrendis hostibus). ${ }^{57}$ But ager captus, as we shall see more fully later on, is ager publicus, and acquired in the sense of ownership, dominium, not simply imperium.

Back in Book II, Grotius offers some further thoughts on the distinction between privately-owned land and territory, again with reference to the Roman ager, in a discussion of what happens to imperium when the course of a river changes. Here, Grotius appealed to the mensores for a threefold

\footnotetext{
${ }^{53}$ DIBP II.3.19.2. Grotius explains dominium eminens at DIBP I.1.6.

${ }^{54}$ DIBP II.2.16, cf. DIBP II.9.7.

${ }^{55}$ DIBP II.22.8.

${ }^{56}$ DIBP II.22. 6, 10 and 12.

${ }^{57}$ DIBP III.6.3.1-2.
} 
division of agri. Some (agri limitati) have artificial boundaries; some are allotted by the universitas according to some system of measurement (Grotius refers to the Roman system of centuriation); yet others have natural boundaries like rivers and mountains, and are called arcifinii, a word (according to the Roman etymologist Varro) that signifies their suitability for warding off enemies (arcendis hostibus).$^{58}$ In the case of such agri, Grotius holds, the alteration in the course of a river does affect the extent of imperium (as not in the others), because we are to understand that the will of the peoples involved on either side was for the river to form a 'natural terminus'. Where there is doubt, imperia which lie next to rivers are to be presumed to be arcifinia, 'because nothing is more apt for distinguishing between imperia than something that cannot easily be crossed. ${ }^{59}$ Going further, however, all imperia are presumed (in the absence of evidence to the contrary) to be arcifinia, 'because that is most appropriate to the nature of territory; but it is more to be believed that private lands are not arcifinii, but either limitati, or contained within a certain measurement, because this is more congruent to the nature of private possessions. ${ }^{, 60}$ At this point, the nature of territory itself takes over from the will of peoples to become the dominant interpretative principle, underlining the distinction between public and private occupation of land. Private ownership is of spaces that are in some sense secondary, artificially delimited or measured in some way. The primary natural spaces of the globe, bounded by natural features, are territory, place subject to sovereignty, place to be defended by public arms against public enemies (hostes). It is noteworthy that in this context, Grotius has come to speak of imperia in something like the modern, fused sense of 'empires', in which the sovereign power and the territory are melded together into one entity.

\section{II - Politics, space and moral reasoning}

With some, albeit indeterminate, picture of the spatially-settled world, then, I want to ask my question again about the space of politics. First I will address the contention that this work is not really about 'politics' at all. This claim has some force. All the material we have been looking at so far comes from the beginning of Book II, the book in which Grotius maps out the field of ius or 'right'. 'Right' in the DIBP is understood principally as individual rights; and these rights are the object of 'commutative justice', the justice of contracts and exchange, rather than 'distributive justice' which, in Grotius's handling, deals not with rights strictly speaking but only with claims. ${ }^{61}$ Grotius's reason for treating them in such depth is that a just cause of war is always a violation of right. Moreover (as we shall see more fully in Sections II and III of this paper), the resort to war is licit where there is no possibility of redress from a judge, that is, where no civil action can be granted the plaintiff: $u b i$

\footnotetext{
${ }^{58}$ DIBP II.3.16.1. Grotius adds that another of the agrimensores, Aggenus Urbicus, calls these agri 'occupatorii', because these are the ones that tend to get occupied in war or because they lie vacant; again he could have found this in Rigault's edition, pp. 148-150.

${ }^{59}$ DIBP II.3.17.2.

${ }^{60}$ DIBP II.8.12.1.

${ }^{61}$ DIBP I.1.4-8.
} 
iudicia desinunt, incipit bellum. ${ }^{62}$ Whether the plaintiff is a public or private body, therefore, it exists insofar as it is a rights-holder within the sphere of commutative justice, while the more political 'distributive justice' is drastically reduced in significance. This anti-Aristotelian, and more broadly anti-teleological, move has been underlined by several recent commentators, although it has clear origins in late scholastic thought, especially in the work of Luis de Molina. ${ }^{63}$ It makes the polis, the 'city', an agent of commerce and indeed itself part of the commerce. Thus, Chapter 5 of Book II, where we find the account of public consociation as a universitas detailed at the start of this paper, discusses the acquisition of right in persons exactly parallel to the acquisition of right in things. Both the universitas and its ruler are subject to the rules of commutative justice: an 'empire of private law', to use Martti Koskenniemi's phrase, to be enforced, in the last instance, by war. ${ }^{64}$

All of this is right. But I think, first, that Grotius preserves more of the Aristotelian polis than is sometimes supposed. An Aristotelian echo is present in Grotius's insistence that the civitas is 'the most perfect society', and gives maximum right to the universitas over its members. ${ }^{65} \mathrm{He}$ uses directly Aristotelian terms and references to describe the internal structure of the respublica and the activity of the ruler within it. Thus, 'Aristotle makes three parts in administering the commonwealth, deliberation on common affairs, the responsibility to select magistrates, and legal judgements' ${ }^{66}$ The art of the ruler is either concerned with universal or particular matters, appealing to Aristotle's distinction in Book VI of the Nicomachean Ethics between two types of political art (politikē), architektonike (involved in legislation) and politike more strictly, that is bouleutike (concerned with the council) and dikastike (concerned with the law-courts) ${ }^{67} \mathrm{He}$ also cites Aristotle's principle that a polis cannot become too large without ceasing to be so, using Aristotle's own analogy of a ship: 'For just as a ship can extend to such a size that it is impossible to be steered, thus both the number of men and the distances between places can become so great, that it cannot support one government. ${ }^{, 68}$

\footnotetext{
${ }^{62}$ DIBP II.1.1.

${ }^{63}$ See Martti Koskenniemi, 'International law and the emergence of mercantile capitalism: Grotius to Smith', in P.-M. Dupuy and V. Chetail eds., The roots of international law / Les fondements du droit international (Leiden: Brill, 2013), 1-37; Straumann, Roman law in a state of nature, pp. 119-129. For the scholastic background, Koskenniemi, 'Empire and international law: The real Spanish contribution', 61 University of Toronto Law Journal (2011), 1-36; Annabel Brett, 'Luis de Molina on law and power', in A. Aichele and M. Kaufmann eds., A companion to Luis de Molina (Leiden: Brill, 2014), 155-182.

${ }^{64}$ Koskenniemi, 'Empire and international law', p. 1. Thus, at DIBP II.24.7, Grotius agrees with Molina that a king who undertakes an unnecessary war is liable under commutative justice to make restitution to his subjects for damages. Again, at the start of Book III (DIBP III.2.2.1-2) on the liability of subjects' goods to reprisals, Grotius argues that in principle they are not liable, because in Roman private law 'it is not the case that what the universitas owes, individuals owe'. That they are in fact so, is a function of the ius gentium voluntarium overriding the usual private law rule.

${ }^{65}$ DIBP II.5.23.

${ }^{66}$ DIBP I.3.6.1.

${ }^{67}$ Ibid. n. 2.

${ }^{68}$ DIBP II.22.13.1. Given that the context here is the rejection of universal dominium of the Roman emperor, Grotius is likely to have culled this Aristotelian point and reference from Domingo de Soto's critique of that universal dominium in De iustitia et iure (Salamanca 1556), Lib. IV, q. 4 ('Whether the Roman emperor is lord of the world').
} 
A second point to be made, though, and more important in the context of this paper, concerns Grotius's language for what we might broadly think of as the political community or association, which is fluid between gens ('nation'), populus ('people'), civitas ('city' in the sense of political community, polis), and respublica ('commonwealth'). All of these involve that moment of 'coming together' (coire), that creation of civil power and civil law, of which we spoke at the beginning. That this is true for gens as well as for the other, more obviously political terms is clear from the opening of Book I, which speaks of the 'disputes of those who are bound by no common civil law, of which kind are both those who have not yet come together into a nation (in gentem), and those who are of different nations between themselves' ${ }^{69}$ It is hard to find clear demarcation lines between the terms. Grotius accents the different elements of terminology differently, however, depending on the context. Thus, it is gentes who are spatially divided. It is populi or whoever commands them, as we have seen, who occupy the land. It is also the populus which pre-eminently carries a political identity, which remains the same despite change of government: the populus Romanus is the classic example, the same under both the Republic and the Principate. It is the civitas which is the association of heads of household into a body politic, and which constitutes the 'common subject' of sovereign power; while the respublica, true to Ciceronian terminology, represents the common bond of right and justice.

It turns out, however, that this Ciceronian definition has to be relaxed if we want to think appropriately about the scope of public war. In Chapter 3 of Book III, Grotius establishes his category of bellum solenne, war that is formally just through being conducted after a formal declaration between two populi having sovereign imperium. This involves him in the contrast with 'pirates' or bands of robbers that Grotius's predecessor Alberico Gentili had so strikingly deployed in this context. ${ }^{70}$ In the Ciceronian tradition, the distinction turns on the justice that characterises respublicae but not pirates or bands of robbers. But here Grotius is keen to insist that a respublica or civitas does not cease to be such the moment it acts unjustly, nor vice versa the band of robbers if occasionally it acts justly; the difference lies in the differing teleology, the one an association for enjoying right and law, the other an association for criminal purposes. ${ }^{71}$ The acts of injustice that a civitas can commit and still be a civitas can be quite extensive and prolonged: thus the Greeks in ancient times lived largely from booty (praeda), though they observed certain rules of the practice. ${ }^{72}$ Likewise, the

\footnotetext{
${ }^{69}$ DIBP I.1.1: controversiae eorum quos nulla juris civilis tenet communio, quales sunt \& qui in gentem nondum coierunt, \& qui inter se diversarum sunt gentium.

${ }^{70}$ DIBP III.3.1.1; for Gentili on pirates, see, among others, Peter Schröder, 'Vitoria, Gentili, Bodin: Sovereignty and the law of nations', in B. Kingsbury and B. Straumann eds., The Roman foundations of the law of nations. Alberico Gentili and the justice of empire (Oxford: Oxford University Press, 2011), 163-186, at pp. 174-8.

${ }^{71}$ DIBP III.3.2.1; cf. the critique in DIBP III.19.2-3 of Cicero's position that we do not have to keep faith with pirates or tyrants. Walter Rech, Enemies of mankind. Vattel's theory of collective security (Leiden-Boston: Martinus Nijhoff, 2013), Introduction and Ch. 2, discusses this aspect of Grotius's law of nations in a broader seventeenth-century context, seeing it as form of international legal pluralism superseded by Vattel's universalisation of the European law of nations.

${ }^{72}$ The reference is ultimately to Thucydides, The war of the Peloponnesians and the Athenians, ed. and tr. J. Mynott (Cambridge: Cambridge University Press, 2013), I. 5-6, p. 5.
} 
Germans were fond of robbery (latrocinia) but were still a populus; so too the Libyan Garamantes, a gens fecund with latrocinia, was nevertheless a gens. Grotius appeals here to Augustine's famous corrective to Cicero in Book IV of The city of God, redefining a commonwealth through concord rather than justice. 'A civitas is still a civitas, even if it is very sick': as long as there remains some system of laws and law courts so that not only the inhabitants, but also strangers can obtain justice there. $^{73}$

I think, then, that what is most interesting about Grotius's conception of political entities is its capacity to embrace the 'ethnological' element inherent in the notion of gentes, and the group identity inherent in populi, together with the more strictly juridical structure of the civitas or respublica with its sovereign imperium and its structure of laws and courts. The contours of the political are limned through a multivalent terminology which deliberately defies any overly-reductive conceptualisation. To return to the start of this section, then, it is certainly true that Grotius subjects both individuals and public corporate bodies to the same justice of contracts and exchange, a line of thought that tends to promote an analogy between individual and 'state' and to depoliticise the latter, making it just one more juridical agent in a potential 'state of nature'. But another line of his thinking pulls in a very different direction, towards a genuinely spatial conception of the polity, a place bounded by mountains and rivers in which a people or a nation with a distinctive identity practises its distinctive form of life with its distinctive institutions. It is this that transforms space into something political in itself.

The key notion doing the work in this more fluid conception is that of 'morals', moralia, a category that Grotius deploys in the same sense as the later scholastics, in talking, for example, of the demand that civil law be 'morally', as opposed to physically, 'possible'. In morals, we reason from the end, and we do not insist on mathematical exactitude. Thus, in the critique of Cicero just mentioned, Grotius asserts that 'in morals (in moralibus), the principal element is taken for the form [of the whole] ${ }^{74}$ Or again, 'in a matter that belongs to morals (in morali materia), those things which are conducive to an end receive their intrinsic value from that end itself: wherefore those things that are necessary to the end of obtaining our right, with necessity understood not according to physical accuracy, but in a moral sense (moraliter), to those things we are understood to have a right [as well]. ${ }^{, 75}$ Again, discussing the time-frame of self-defence, Grotius argues that 'in morals' - though in

\footnotetext{
${ }^{73}$ DIBP III.3.2.2. The importance of the teleological perspective, and the significance of Grotius's use of Augustine against Cicero, is stressed by Daniel Schwartz, 'Grotius on the moral standing of the society of nations', Journal of the History of International Law 14/1 (2012), 123-146, at pp. 139-140, who also highlights the role of the voluntary law of nations in addition to the natural law.

${ }^{74}$ DIBP III.3.2.2.

${ }^{75}$ DIBP III.1.2.1.
} 
this case there is an analogy with 'naturals' - a point of time (punctum) always has 'a certain latitude' ${ }^{76}$

For present purposes, the most important place in which the kind of reasoning appropriate to 'morals' impacts upon the conception of politics is back towards the beginning of Book II on the subject of original acquisition, when Grotius, having dealt with the land, considers fish, birds and wild animals. In principle, these are the classic case of 'things that belong to no one' (nullius), which thus, under natural law, can be 'occupied' by anyone, in any place. But Grotius argues that the holder of imperium over land and the adjoining sea $^{77}$ can by civil law prohibit the acquisition of these things without contravening natural law. ${ }^{78}$ Further, he stipulates that such a prohibition would apply not only to his own people but to foreigners as well, aligning himself with the common late-scholastic principle that a foreigner is obliged by the laws of the country he is visiting. 'The reason is, that for the government of a people it is morally necessary that those who mingle with them even only temporarily, which happens on entering the territory, should render themselves conformable to the institutions of that people. ${ }^{79}$ If this is not strictly an Aristotelian teleology of 'the best', it is nevertheless a distinctive moral teleology of ordered political life, which brings a 'moral necessity' in its wake. Political life cannot tolerate strangers disobeying laws that inhabitants are forced to observe: disorder would ensue.

What Grotius here rejects is a kind of picture in which foreigners, not being members of the civitas which they enter, remain, even when they are within it, under natural law rather than civil law: that is,

\footnotetext{
${ }^{76}$ DIBP II.1.5.1.

${ }^{77}$ As is well-known, Grotius's positon in DIBP is modified vis-à-vis the earlier works to allow some sort of local 'occupation' of the sea, at least in respect of imperium, as long as the extent of that occupation is not disproportionate to the land: DIBP II.3.8 and 13.

${ }^{78}$ DIBP II.2.5. Grotius cites for this point Diego de Covarruvias, In regula peccatum Pars II, § 8, which concerns hunting: Opera omnia (Frankfurt 1592), Tom. I, fo. 534. Covarruvias's work had been a significant source for Grotius in De iure praedae, too, with a reference to this specific locus in Ch. 12 of that work: Hugo Grotius, De iure praedae commentarius, tr. G. L. Williams in M. van Ittersum ed., Commentary on the law of prize and booty (Indianapolis: Liberty Fund, 2006), Ch. 12, p. 354. However, Grotius had there used Covarruvias purely for the technical distinction between 'negative' and 'positive' community; here the use is different, suggesting Grotius revisited Covarruvias in the context of the new argument he wanted to make in DIBP.

${ }_{79}$ Ibid.: Ratio est, quia ad gubernationem populi moraliter necessarium est, ut qui ei vel ad tempus se admiscent, quod fit intrando territorium, ii conformes se reddant ejus populi institutis, with a marginal reference to commentaries on the canon law: Dd. in l. cunctos populos. C. de summ. Trin. Innoc. \& Panorm. in c. a nobis. I. de sent. excom. (again the placing of the marginalia is clearer in the 1625 edition). It is worth comparing Grotius's Latin text and reference with Francisco Suárez's assertion of the capacity of civil law to oblige foreigners: [lex] obligat omnes actu ibi degentes pro tempore, quo ibi commorantur. Probatur consequentia primo ex parte causae finalis, quia ad bonam gubernationem provinciae, loci, seu territorii, est moraliter necessarium, ut leges pro illo latae hanc vim habeant, quia ad pacem, et ad bonos mores loci necesse est, ut advenae conformentur moribus populi, quamdiu ibi versantur (Francisco Suárez, De legibus ac Deo legislatore, here in the edition of Mainz 1619, Lib. III, cap. 33). Suárez's reference is to communis sententia interpretum in l. cunctos populos. C. de summa Trinitate, et in cap. a nobis, I. de sentent. excommunicat. Presertim Innoc. Hostiens. et Panormiram. [sic] et in cap. 2. De constitution. in 6. ubi late Gemin, \& Sylves. verb. excommunicatio, 2. $n$. 4. Grotius's version is more compressed and more elegant, but the similarity of language between the two is unmistakable. See further Brett, Changes of state, pp. 171-181, for the position of Jesuit writers on the obligation of travellers.
} 
in a 'state of nature'. In this picture, foreigners may, by the natural law which governs the state of nature, lay their hands on any fish or birds or wild animals that roam around in the territory - which, in fact, does not have that identity as 'territory' under natural law, being merely natural place. This is exactly the scenario that he himself had invoked, in his earlier De iure praedae, to defend his position that punishment is a natural right: 'the state inflicts punishment for wrongs against itself, not only upon its own subjects but also upon foreigners; yet it derives no power over the latter from civil law, which is binding upon citizens only because they have given their consent; and therefore, the law of nature, or law of nations, is the source from which the state receives the power in question. ${ }^{, 80}$ As Richard Tuck remarked long ago, this is the same argument that John Locke would use for the same purposes in the Second Treatise of Government. ${ }^{81}$ But we can now see why Grotius dropped it from DIBP. Although, in Chapter 20 of Book II of that work, Grotius retained a defence of the natural right to punish, the 'alien argument' for it is not only redundant, but goes against everything that Grotius wants to say about the necessary implication of space and political power, which does not rest on personal consent alone. ${ }^{82}$ It also goes against everything he wants to say about the space of war under the voluntary law of nations, to which I now turn.

\section{II - THE SPACE OF WAR}

Grotius defines war as 'the state of those contending by force' (status per vim certantium). ${ }^{83}$ War divides into private, i.e. on the part of private individuals, and public, i.e. on the part of those who hold summum imperium, although it is important that these too are individual human agents. With one exception, as we shall see later on, Grotius does not think of 'the state' - for which he has no one word anyway, as we have seen - as an agent, a 'moral person' as the later tradition would have it. ${ }^{84}$ Of these two kinds of war, Grotius says, private war is 'more ancient', 'before' the establishment of iudicia, i.e. civil law courts. ${ }^{85}$ Given that he asserts that war begins where courts stop, we apparently have a picture of a time, prior to the institution of the civitas with its civil law and courts, in which the only remedy for violation of right was force: a 'state of nature', no less, which would have been spatially unlimited because there were as yet no territorial boundaries. Just as this space was modified by civitates with their territories, so the natural rights of individuals to resort to force - both to defend and to punish - were restricted by the establishment of civil remedies. However, these natural rights

\footnotetext{
${ }^{80}$ Grotius, De iure praedae, ed. van Ittersum, Ch. 8, p. 137.

${ }^{81}$ Tuck, Natural rights theories, pp. 62-3. John Locke, Two treatises of government, ed. P. Laslett (Cambridge: Cambridge University Press, 1988), Second treatise, Ch. 2, § 8.

${ }^{82}$ Compare Gustaaf van Nifterik, 'Grotius and the origin of the ruler's right to punish', Grotiana 26/1 (2005), 396-415, who likewise distinguishes between the theory of De iure praedae and of DIBP, albeit from a different perspective.

${ }^{83}$ DIBP I.1.2.1.

${ }^{84}$ This point is stressed by Peter Haggenmacher, Grotius et la guerre juste (Geneva: Droz, 1983), pp. 541-543.

${ }^{85}$ DIBP I.3.1.1; 1.3.2.1.
} 
remain in force, and therefore private war is justified, after the establishment of civitates in certain circumstances. Such circumstances occur either temporarily, when recourse to a judge cannot be had before serious harm occurs; or continuously, and in this case either de jure or de facto: de jure, 'if someone is about in unoccupied places, for example the sea, the desert, empty islands, and if there are any other places where there is no civitas', and de facto, if subjects do not accept the judge or vice versa. ${ }^{86}$ Compare the very opening sentence of the book, part of which we looked at earlier: 'The disputes of those who are bound by no common civil law, of which sort are both those who have not yet come together into a nation, and those who are of different nations among themselves, both private individuals and kings themselves, and any who have a right equal to that of kings, whether these be senators (optimates), or free peoples, [these disputes] belong either to time of war or to time of peace.' We seem to have a very strong analogy, then, between a 'state of nature' and the international realm, and between private individuals and public sovereigns (again, not between private individuals and states). ${ }^{87}$

One difficulty with this account comes with the spatial scope of the state of nature. We have already seen, in the case of aliens, how Grotius's territorial argument circumscribes the natural right to punish in DIBP. Apart from the high seas, the deserts that Grotius equates to seas, ${ }^{88}$ and the uninhabited islands that we have already encountered, therefore, the space of this natural right can only exist 'where there is no civitas'. In Book II Chapter 20, Grotius argues that the natural right to punish was operative 'before' civitates and is still in force, in places where human beings (homines) live distributed in families rather than civitates. ${ }^{89}$ This language echoes his description of the formation of political community in Chapter 5 of that book: a 'consociation, by which many heads of household (patres familiarum) come together into one people and civitas ${ }^{9}{ }^{90} \mathrm{We}$ can now see, however, that Grotius's appropriation of this scholastic account is in this respect problematic, because the sacred history narrative of settlement that Grotius offers suggests that families are already part of gentes, and Grotius's political language, as we have seen, equates the existence of gentes with civitates and with the existence of civil law. While, in DIBP, he shares with them the narrative of an original spatial division of the world into gentes, the scholastics had not formally equated gentes with civitates. Thus, in the eyes of Luis de Molina, Grotius's target in the question of punishment, it was perfectly possible that there might indeed be some places where gentes lived in family groupings without having yet formed a civitas, 'as is apparently the case in the region of Brazil'. ${ }^{91}$ In such a situation, Molina argued, heads of families must take the place of sovereigns and wield a public right to punish. Grotius

\footnotetext{
${ }^{86}$ DIBP I.3.2.1.

${ }^{87}$ Straumann characterises the high seas as 'an actually existing state of nature': Roman law in the state of nature, pp.147-156; Tuck, The rights of war and peace, pp. 6-8, also argues that the concept if not the specific phrase is operative in Grotius.

${ }_{88}^{88}$ DIBP II.2.3.2.

${ }^{89}$ DIBP II.20.40.4.

90 See above, n. 15.

${ }^{91}$ See Molina, De iustitia et iure, Tract. II, disp. 100 nn. 6-7 and disp. 22 n. 9.
} 
turned the argument around to make the public right a natural right (not without some prompting from Molina himself, who had admitted the possibility only to reject it). But this leaves a possible scenario of lands populated by isolated families for which Grotius offers no explanation. ${ }^{92}$ This may account for his hesitation in affirming that such places definitely exist.

There are also, however, tensions that strain the analogy itself. We can see this if we investigate a little bit more closely the natural right of self-defence that both public and private individuals possess. Self-defence is equally legitimate for both. And yet, although the action on both of their parts is analogously just under the law of nature, it is disanalogous in other ways. For a private individual, what is in question is 'present force' against his body, 'with danger of death no otherwise avoidable' ${ }^{93}$ Private self-defence, then, is in puncto: at a specific point in time. As always in 'moral matters', we are not talking mathematics; as we have seen, there is a certain latitude - one does not have to wait for the weapon actually to touch one's body. However, more extended temporal anticipation is illicit: 'in private war the right is quasi-momentary, and ceases as soon as the matter allows access to a judge'. ${ }^{94}$ But the case is different for public powers, where there is indeed no judge: here even a war of self-defence has extended temporal duration, being perpetuated by every new act of injustice. It is, moreover, inevitably mingled with the right of revenge, which public powers have and individuals do not. As a result, 'it is licit for them to prevent force not only present, but which is seen to be imminent from afar, not directly (for we have already taught that that would be unjust), but indirectly, by revenging a crime that has already begun but has not yet been consummated. ${ }^{95}$ This discussion is about temporality, but it also, implicitly, about spatiality as well, the proximity or otherwise of bodies and bodily contact. Both factors make the moral casuistry of war very different for a public power than for a private individual.

Moreover, the analogy only works for private and public individuals with a just cause of war under natural law. That is, private just war and public just war are - to some degree - analogous. But if it is two public individuals who are fighting each other, then, whatever the natural justice of the cause, this entirely public character of a war moves it into a separate legal order in which different rules apply: the 'voluntary law of nations', not natural law. A publicly-declared war between two public powers is bellum solenne: 'solemn', or formal war, which is not the same thing as a just war (though a war could be both just and solemn at the same time, but only on the side of the one who had the just

\footnotetext{
${ }^{92}$ It is true that Grotius posits a natural right of punishment against barbarians whose violation of natural law is so egregious as, implicitly, to deny them civitas status, for example the Sogdians: DIBP II.20.40.3. But Grotius does not equate the pre-political, familial state with the systematic violation of the law of nature practised by these groups.

${ }_{93}^{93}$ DIBP II.1.3.

${ }^{94}$ DIBP II.1.5.1, II.1.16.

${ }^{95}$ DIBP II.1.16.
} 
cause). Bellum solenne triggers legal effects for both parties - whether their cause is just or unjust that a private war does not, and neither does an 'improper' war like a civil war. ${ }^{96}$

Book III of DIBP considers the legal effects of bellum solenne. It is here that the spatiality of the gentes comes to the fore, both in the operation of these legal effects and in generating the norms of the 'voluntary law of nations' in the first place. We have already seen how, in the context of introducing the notion of bellum solenne, Grotius relaxes the strictly juridical definition of the civitas. He proceeds to detail its two principal effects, which are, first, a laedendi licentia - a licence to hurt and to kill the body of the enemy (there is an interesting similarity of language here with that which Grotius uses to characterise the 'age of giants': caedium licentia, licence of slaughter.) This is not a moral licence, but represents only impunity: a mutual agreement of the nations not to punish the perpetrator as a murderer nor otherwise to wage war on him for his deeds, should he come into their territory. ${ }^{97}$ Unlike a right arising from a just cause under natural law, this right under the voluntary law of nations is not confined to the party with the just cause: it is unlimited and applies equally on both sides. As for why the nations would have agreed to this principle, Grotius argues that otherwise other nations would be drawn into the war, forced to decide whether one side was in the right or the wrong. ${ }^{98}$

Under the voluntary law of nations, an enemy equally spatially defined. Enemies are not only 'those who actively bear arms, or who are subject to the one who makes war, but everyone within enemy borders'. ${ }^{99}$ That includes those who travel there knowing of the situation, although foreigners who happened to be there at the outbreak of war should be given an opportunity to leave. The reason is that anyone within enemy borders could be a cause of harm to the other side. Nevertheless, there remains a distinction between such accidentally spatially-located individuals and those who are legally the subjects of the enemy sovereign. On these latter, war is personally declared just as it is on their ruler. And because of the personal quality of their enmity, they can in principle be attacked 'everywhere', ${ }^{100}$ and indeed by anyone: under the voluntary law of nations, 'enemies are deemed to be as nothing', hostes pro nullis habentur. ${ }^{101}$ The right of war 'is, of itself, not enclosed by territory' ${ }^{102}$ Thus 'on their own ground, or on their enemy's, on ground belonging to no one (in solo nullius), on the sea', they can be killed with impunity. But commonwealths that are in a state of peace with both the warring parties can limit the operation of this licence on their territory (in territorio pacato): 'for civil societies could establish that nothing should be done by force to those who were in a certain

\footnotetext{
${ }^{96}$ For 'war in due form', see Stephen Neff, War and the law of nations. A general history (Cambridge: Cambridge University Press, 2005), Ch. 3, esp. pp. 95-103 for Grotius.

${ }^{97}$ DIBP III.4.2-3; laedendi licentia at III.4.5.1, caedium licentia at I.1.5.1.

${ }^{98}$ DIBP III.4.4.

${ }^{99}$ DIBP III.4.6, appealing to Livy XXXVIII.48: hostis sit ille, quique intra praesidia ejus sunt. The list of those who can be killed includes women and children, captives, those who have surrendered, hostages (III.4.9-14).

${ }^{100}$ DIBP III.4.8.1, ubique locorum.

${ }^{101}$ DIBP III.18.1.2.

${ }^{102}$ DIBP III.21.22.
} 
territory ${ }^{103}$ The case is, in fact, exactly parallel with the rules on the prohibition of hunting that we considered in the previous section, in a non-bellicose context.

Grotius goes on to make this clear in his chapter on acquiring goods in war. The second major legal effect of bellum solenne is mutatio dominii, change of dominium. Goods captured by the enemy become the property of the enemy in the sense that all nations will defend both the one who captured the goods, and anyone whose title to them depends on that capture, in the possession of them. ${ }^{104}$ It is similar to occupatio in being a natural and original mode of acquisition (Grotius appeals here to Aristotle's definition of the art of war as naturally acquisitive): natural in the sense that it does not require a 'cause' but is a right arising from the pure fact of capture. ${ }^{105}$ The parallel is underlined by Grotius's assertion that 'the nations agreed that the goods of enemies (res hostium) should be to their enemies in no other position than are res nullius' ${ }^{106}$ What, however, counts as 'capture'? Here again a spatial dimension is key. A thing is deemed to have been captured where there is no hope of recovering it, or it is beyond pursuit: effectively, when it has been brought within the borders or within the 'garrisons' (praesidia) of the enemy. The requirement of non-recoverability also generates a certain temporal condition, of more than temporary capture; but this demand is satisfied by fortifications, as in the ager captus we noted above, concerning the definition of territory; or by sheer force, for example bringing goods captured at sea back to 'where the whole fleet is' (i.e. not simply back to naval bases or harbours). ${ }^{107}$ In the case of goods captured from the enemy outside the territory of either party waging war, however, the right of capture can be restricted by the ruler of the relevant territory just as can the killing of enemies - the rationale of the human being and the thing being the same. $^{108}$

Implicit in bellum solenne, then, as opposed to bellum justum, is that there are not only two parties. In a war that is just by natural law, all that needs to be considered, for a legal analysis of the action, is that nature and cause of the two contenders. It isolates them juridically. But this is not so for bellum solenne, which takes place amidst other states. These states modify the space of war, providing a kind of juridical exoskeleton. Crucial to this function in territorialising an otherwise unterritorial right of war is the principle, first encountered in the peacetime activity of hunting, that foreigners entering a territory have to submit to its laws. Enemies might be pro nullis to each other, their property res nullius to each other, but they are not so to third parties, nor are they in the state of nature with respect

\footnotetext{
${ }^{103}$ DIBP III.4.8.2.

${ }^{104}$ DIBP III.6.2.1. Grotius characterises the acquired ownership as dominium externum - dominium solely through external effect.

${ }^{105}$ DIBP III.6.2.4; Aristotle, Politics I.8, 1256b20-25. See Haggenmacher, Grotius et la guerre juste, p. 254 for the Roman law principle that goods captured in war become the property of the captor, and the parallel with the hunter and his prey.

${ }^{106}$ DIBP III.6.8.

${ }^{107}$ DIBP III.6.3.2. Grotius notes, though, that recently 'European peoples' have enforce a purely temporal 24hour rule.

${ }^{108}$ DIBP III.6.26.2; III.6.3.2. Cf. III.6.13.
} 
to those third parties. Rather, they are subject to their law and their courts. Given that bellum solenne is the key institution of the voluntary law of nations, Grotius's entire analysis of this law depends on this fundamental principle.

\section{III - AGENCY}

Having mapped out the spatial dimensions of both political communities and war, I want to turn to how spatiality intersects with questions of agency and action. To begin with some generalities, Grotius, like all his contemporaries within the natural law tradition and within philosophy and theology more broadly, has a philosophy of action and agency which privileges the 'internal act', the act of the soul or mind, over the 'external act', the physically embodied spatio-temporal action. The 'internal act' can be an act of reason or of will, but in agency the act of will is more prominent because of the motive force of the will which the intellect is not held to possess in the same way. The will is responsible for the moral quality of an action and it is also, at least in the voluntarist way of thinking to which Grotius rather shakily adheres, responsible for legal and juridical effects such as (principally) obligation. Thus, in the analysis of promising, it is the internal act of will that 'deliberates' or obliges the promiser. ${ }^{109}$ Equally importantly, however, the example of promising shows that the act of will is insufficient by itself: as an 'internal' act, it cannot be known to another unless some 'sign' of that will is given, and it cannot be accepted by another unless that other gives some sign in return. Thus, the legal effect of promising is not generated by the act of will alone. Grotius holds that for an unsignified will to have legal effect is 'inconsistent with human nature'; however, equally it is likewise inconsistent that a signified will have no effect at all. ${ }^{110}$ Grotius offers these thoughts in his analysis of the celebrated Roman legal process of 'prescription', whereby the passage of time leads to the loss of right on the part of one and the acquisition of right on the part of the other. Like two other processes, occupatio and custom, prescription generated reams of early modern commentary precisely because it did not seem to involve the act of will necessary for legal effect. But, as with occupatio and custom, Grotius finds a presumed act of will involved - as he does too with mutatio dominii through war: although he says that it arises from pure fact, it is the consent of the gentes that allows it to have the status of dominium (or at least, 'external' dominium). In sum, then, this kind of analysis of action might seem to leach any legal quality out of the physical, spatial acts involved. But in fact it is precisely the need - the moral necessity - to accommodate such acts within the law that makes an act of will implicit within them, as in the tacit consent which is simultaneous with occupation. They also become key to legal interpretation, because, in the absence of words - and even in their presence, since words can be ambiguous -, they are what constitutes a

\footnotetext{
${ }^{109}$ DIBP II.11, 'On promises'.

${ }^{110}$ DIBP II.4.3.
} 
sign of the will. This is especially so since the will has to be read off from signs in a manner that can carry only probability rather than certainty. ${ }^{111}$ Thus, in an example we looked at above, the legal presumption that imperia are arcifinia is an interpretative position governed by the sheer nature of territory itself, as physical space to be defended from enemies.

What, then, about agency in war? Somewhat surprisingly, Grotius (as we have seen) deliberately defines war at the outset of the DIBP as a 'state', not an 'action'. Thus, although Cicero had said it was 'contest by force', it is rather 'the state of those contending by force'. ${ }^{112}$ This marks a shift from his earlier De iure praedae, in which war was centrally defined as an action, that of 'armed execution upon the armed'. ${ }^{113}$ If we look at Grotius's notes to the new definition, however, we see that 'state' principally refers to a distinct time of war, which includes not only the actual fighting but also preparations to fight. ${ }^{114}$ Within this time, Grotius continues to be principally concerned with the justifiability of acts of war. As Peter Haggenmacher observes, war as a 'state' only recurs very late in Book III, in which Grotius discusses truce as a cessation in acts of war but not in the war itself. ${ }^{115}$ Apart from that, the new definition appears to do no work.

One effect, however, of defining war as a 'state' rather than an action is that De iure praedae's distinctive analysis of the action of war in terms of the four causes of Aristotelian science is lost, though it continues to impact on the organisation of the work. ${ }^{116}$ Those four causes are 'efficient', 'material', 'formal' and 'final'. In terms of the second, Grotius in De iure praedae distinguishes the causa materialis circa quam ('material cause with regard to which') by which he means the thing that is in contention, effectively the 'just cause' of more traditional language, and the causa materialis in qua ('material cause in which'), which is the bodies of the enemy - the bodies that are 'justly hurt', juste laeduntur, in a just war, which is an action that begins in the will of the belligerent and ends in a body. As Haggenmacher notes, all of Book II of DIBP is devoted to the just cause in the first sense, while the second, the bodies of the enemy, is almost (although not totally) elided ${ }^{117} \mathrm{I}$ am not sure that the elision goes as far as this; Book III, with its laedendi licentia, licence to hurt, is littered with bodies: the bodies of 'hurt' enemies, but also the bodies of women, working animals, and trees, all of which Grotius holds should not be regarded as just objects of belligerent action. ${ }^{118}$ All of these, as concrete material objects, are spatially situated, integrated in the inevitably spatial action of war. One

\footnotetext{
${ }^{111}$ Ibid.; there is a great deal more to be said on signs and spaces of communication more generally in the DIBP, esp. II.16, 'On interpretation'.

${ }^{12}$ DIBP I.1.2.1.

${ }^{113}$ Grotius, De iure praedae, ed. van Ittersum, Ch. 2, p. 50.

${ }^{114}$ See Haggenmacher, Grotius et la guerre juste, pp. 457-459, to which the following analysis of agents and actions is much indebted.

115 DIBP III.21.

${ }^{116}$ Ibid., pp.64-6 for the four causes in De iure praedae.

117 Ibid., p. 559.

${ }^{118}$ DIBP III.4.19 on the rape of women, disallowed even under the rules of bellum solenne, let alone a just war; DIBP III.12, 'Moderations in respect of devastation, and similar', for trees and animals.
} 
thing we might add, though, is that even in De iure praedae, there is no causa materialis ex qua, 'material cause out of which' - there is no body of the belligerent. The belligerent's body seems to disappear into his nature as an 'efficient cause', the motive force or mover, of the action.

What does efficient causality require? Both works - although I return here principally to look at the DIBP - insist, true to the model of agency outlined above, on the action of war as voluntary action, an act of will. ${ }^{119}$ In voluntary action, the principal agent is the one who acts at his own will: a private individual in a private war, the supreme power in a public war. But other agents can be instruments of the principal: not instruments in the sense of will-less automata, but those "who act at their own will such that that will depends upon another'. ${ }^{120}$ Agents of this kind are, for example, a son in respect of his father, or a servant (servus) in respect of the household (familia): appealing to Book $\mathrm{V}$ of Aristotle's Nicomachean Ethics, Grotius argues that these form 'part' of the father and the household respectively. Aristotle had in fact declared that the servus - the slave - forms part of the master, but that would destroy Grotius's next point, which is that the position of the subject in the commonwealth is analogous to that of the servant in the household, 'and is thus the instrument of his superior'. ${ }^{121}$ Instrumentality, then, is a way of extending voluntary agency through space. This does not mean, however, that such instruments are not capable of independent agency and therefore of justice or injustice in war. They come up again, with the same reference to Aristotle, at the end of Book II, on the question whether those who are bound to obey their superiors need any other cause of war to justify their action. The answer is yes: certainly they should disobey their superiors if order to do something contrary to God's command; but even in case of doubt, it is not enough to adopt a default position of obeying one's superior. One should abstain. Christians should not be forced to fight in any war, even a just one. ${ }^{122}$ The correct interpretation of the argument about 'instruments', then, seems to be that a subject makes himself the instrument of his superior in obeying; not that he just is an instrument. There remains a choice whether to obey or disobey.

The instrumental conception of action, therefore, reduces the action back to the act of will, thus again seeming to squeeze spatial dimensions almost entirely out of the relevant concept of action. But the spatiality that seems inconsiderable if we are talking about one individual as the instrument of another does not seem so marginal if what we are talking about is a multitude of individuals - an army (exercitus). What is an army? Grotius provides no direct definition, and this is deliberate. It is a matter of interpretation, the field of signs to which we referred at the start of this section: signs that are both physical in themselves, but are also enmeshed in a broader physical world, the world we live in. Thus, in Book II Chapter 16, the chapter on the interpretation of signs, Grotius argues that if in agreements

\footnotetext{
${ }^{119}$ DIBP I.5.1.

${ }^{120}$ DIBP I.5.3.

${ }^{121}$ Ibid. Notice again that he is not an instrument of the commonwealth itself, which is not figured as a voluntary agent.

${ }^{122}$ DIBP II.26, 'On just causes of war being waged by those who are subject to the imperium of another.'
} 
mention is made of an army, let us define an army as that multitude of soldiers, which dares openly to invade enemy borders. For historians continually oppose that which happens furtively, or in the manner of robbers, to that which takes place by a just army [sc. 'just' in the sense of legally just, 'formal']. Which is why one should judge by the strength of the enemy, what number of men makes an army'. ${ }^{123}$ Thus, the physical act of marching brazenly across the borders, a physical act associated with a certain number of people (depending on the circumstances), is centrally implicated in the conception of the key instrument of formal war, an army. Likewise, a 'fort' is a place that can hold off the enemy for some time. ${ }^{124}$

Grotius presses further on the instrumental model when he comes to consider, in Book III, the issue of prize or booty. Does anything captured belong as booty to the individual soldier who captured it? In Grotius's estimation, the common opinion is yes. But if so, then in all cases individual soldiers are like hunters catching rabbits, private agents rather than instruments of a public agent: the war might be public but the component acts are not. Self-consciously against the general perception, Grotius distinguishes acts on the part of soldiers undertaken 'in public service' (in ministerio publico) from those done privately; in the former, what is captured is acquired by the 'people', not the soldier. This constitutes the distinction between truly public acts of war and private acts which take place with the occasion of a public war. ${ }^{125}$ But how do we know which is which? Grotius tackles two different types of acquisition in turn. In the case of ground (res soli), this 'cannot usually be captured except in a public act, bringing in an army, with garrisons erected'. Again the model is, implicitly, the Roman ager publicus. ${ }^{126}$ Temporary possession by an army is not enough, however: it needs to be fortified and defended. Hence the definition of territory from 'terrifying enemies' that we examined earlier in the paper. ${ }^{127}$ In the case of mobile rather than immobile goods, Grotius again wants to avoid the position that in all cases these fall to the individual soldier who takes them. Again, how do we distinguish when a soldier is acting as an instrument of a superior, and when he is acting on his own initiative? One factor is whether the soldier is acting directly under orders. In such a case, he is clearly not the principal agent. But, interestingly, this is not the only factor. Grotius refers to what soldiers capture when they are not in procinctu, in battle or other military enterprise, or what they capture when they are apart from the army (the Romans specified ten miles away). ${ }^{128}$ It seems, then, that

\footnotetext{
${ }^{123}$ DIBP II.16.3. The eighteenth-century English translation misleadingly has 'publicly' for the Latin aperte, suggesting some intrinsic component of 'publicness' to the definition of an army, whereas the public character is in fact a function of the openness of the action. There follow a series of very different Roman definitions of how many soldiers makes an army.

${ }^{124}$ Ibid. Grotius offers these instances ('army', 'fort', and also 'fleet') as examples of technical terminology that the mass of the people does not understand, making no differentiation between such terms and other more obviously technical terms such as 'majesty'. I take it that the historical knowledge Grotius sees as implicit in interpreting 'army', at least, is the relevant 'art' that the vulgar do not possess.

${ }^{125}$ DIBP III.6.9.1, III.6.10.

${ }^{126}$ DIBP III.6.11: publicatur ager qui ex hostibus captus sit.

${ }^{127}$ DIBP III.6.4.1-2.

${ }^{128}$ III.6.12.2, referring to 'what the Italians nowadays call correria, which they distinguish from booty (butino)'.
} 
formally speaking the only truly public acts of war, actus bellici, are acts involving an army (the note by Grotius's commentator Gronovius on the phrase actus bellici reads: 'as in a line of battle, or the siege of a city'). ${ }^{129}$ Grotius's insistence on the necessarily public character of such an act is in fact strong enough for him to change the model of agency. In such an act of war, members of the army are no longer said to be 'instruments' but 'representatives' - and not representatives of the sovereign, but representatives of the commonwealth itself: 'individuals (singuli) bear the person of the commonwealth, and act as its vicegerents (eiusque vice funguntur). ${ }^{130}$

Capture by an army, then, is capture by the political community itself. As far as I can see, this kind of act of war is the only act in the entire DIBP in which the commonwealth itself is said to act, implicitly as a person, through soldiers which bear its person. The personal model of agency involved might seem to take us back to De iure praedae and its strict parallel between private and public occupation ('the occupancy of public possessions is achieved by the same method as occupancy of private possessions'). But in fact both the public captor - the army - and what is publicly captured are distinguished from the private by their spatial extension. The analysis of capture in war, then, is continuous with the earlier story concerning the occupation of land. In both cases, it is, in its very capture of space, a centrally political act. The continuity of language is suggestive, too. Grotius there stated that occupation per universitatem takes place through the people, or he who commands (imperat) the people: a figure whom we might now identify as the imperator, the general of an army. Moreover, we also saw him assert that 'sovereign power has two subject matters, primarily persons, which is sometimes enough on its own, as in a company' - or, we might now say, an army? (exercitus) - 'of men, women and children seeking a new home, and secondarily place, which is called territory. ${ }^{131}$ I want to suggest, then, that exercitus is Grotius's fifth term, after gens, populus, civitas, and respublica, for limning the contours of the political community. A body politic on the move, detached from place, is an army; conversely, the army is, through representation, the body politic in another place.

\section{CONCLUSION}

'Huge is this your kingdom', proclaims DIBP's dedicatory letter to Louis XIII, 'which runs through so great spaces (spatia) of such happy lands to both seas: but it is kingdom greater than this kingdom, that you do not covet other kingdoms,' nor 'disturb the old boundaries'. ${ }^{132}$ Right at the start, Grotius's invocation of the geographical space and situation of France sets the agenda for a work that I have sought to analyse as a law of war and peace for a situated world. His conception of political

\footnotetext{
${ }^{129}$ DIBP III.6.14.1.

${ }^{130}$ Ibid.

${ }^{131}$ DIBP II.3.4.1

${ }^{132}$ DIBP 1720, sig. *3 v; 1625, sig. ã iii r; ed. Tuck, Vol. I p. 72.
} 
community includes spatial extension at its core, a relationship between politics and place that began in 'the first times', prima illa tempora, with the dispersal of the gentes and the concomitant division of lands following the destruction of the tower of Babel. The model of agency that he deploys remains one of personality, in which spatial extension has to be theorised on a model of instrumentality or, uniquely in the case of the army, representation. But it is remarkable that the commonwealth itself appears only to acquire this personality in that one instance of a spatially extended act, the occupation of land. Grotius otherwise resists theorising the international arena in terms of states as persons, a lens, as suggested at the outset, which precisely makes it hard to see those spaces of sovereignty that both we and Grotius call imperia, empires.

Spatiality and agency intersect partly because voluntary actions acquire their signification in space, partly because voluntary actors move through space. Spatial division allows for movement both private and public, of individuals and of peoples. Private movement - trade, travel, the acquisition of natural resources - is largely favoured by Grotius, contained as it is within the geo-political order: unconstrained in spaces not occupied by the gentes, subjected to civil law in spaces that are. Grotius is more ambivalent in respect of public movement, however. Under natural law, it is licit for peoples to occupy any lands that have remained unoccupied after the original division; it seems clear, indeed, from his description of agri arcifinii, that the current pattern of settlement is the result of a history of occupation as well as division. But, while there is apparently still room for further public movement of this kind, he does not positively advocate settlement in the present; his example of a people seeking novae sedes is one of forced exile. Notoriously, his theory does allow for a natural just war on the part of public agents against groups which systematically violate the law of nature. ${ }^{133}$ And yet, as we have also seen, gentes can remain gentes - and thus under the rules of bellum solenne, not natural justice even with quite a high degree of technically unjust behaviour. Again under the voluntary law of nations, Grotius allows land capture by armies, and the acquisition of imperium. ${ }^{134}$ But he does not approve the practice unless absolutely necessary for security; even then, he advocates leaving the conquered with as much imperium as possible. Grotius's anti-Bodinian argument for the divisibility of sovereignty (imperium) allows precisely for this. ${ }^{135}$ As his dedicatory letter to Louis XIII suggests, the morality of international politics seems to be one of leaving things in place.

To sum up, and to return to the Introduction, Grotius's global political world in DIBP is not primarily one of sovereign states as international actors, but of land spaces over which sovereign power

\footnotetext{
${ }^{133}$ See above, n. 91.

${ }^{134}$ DIBP III.8.1; the illustrative quotations here show that imperium is meant in its sense both of power over people and of spatial extent.

${ }^{135}$ DIBP III.15, 'Moderation concerning the acquisition of imperium', cf. DIBP I.3.17. Tuck, The sleeping sovereign, pp. 85-86, argues that while Grotius's conception of sovereignty is essentially scholastic (with which I agree), he is closer to the modern concept of sovereignty in the international domain. I think, however, that Grotius's scholastic, teleological conception of sovereign power crosses both the internal and the external dimensions of politics, and is precisely of a piece with his 'moral' reasoning about political space.
} 
(imperium) is exercised. It is governed by a law (ius) of war and peace that does indeed rest upon a core of natural rights (iura), but which is nevertheless conditioned in its application by a supple form of 'moral' reasoning which spatially limits the operation of natural law. Along with its flexibility in the location of sovereign power, this vision lost out to the seductive appeal of states as moral persons which would go on to form the basis of the early modern 'law of nations'. I have tried to suggest that a sophisticated international political thought was lost in that process. 